九州大学学術情報リポジトリ

Kyushu University Institutional Repository

\title{
Production of Interspecific Germline Chimera between Quail and Chicken Utilizing the Cells from Central Disk of Blastoderm and Germinal Crescent Region
}

Soh, Tomoki

Laboratory of Reproductive Physiology, Division of Animal Science, Department of Animal and Marine Bioresource Sciences, Faculty of Agriculture, Kyushu University

Inoue, Yoshie Laboratory of Reproductive Physiology, Division of Animal Science, Department of Animal and Marine Bioresource Sciences, Graduate School of Bioresource and Bioenvironmental

Sciences, Kyushu University

$X i$, Yong Me i

Laboratory of Agticultural Ecology, Division of Agricuktural Ecology, Department of Plant Resources, Graduate School of Bioresource and Bioenvironmental Sciences, Kyushu University

Kato, Yukio

Faculty of Agriculture, Meiji University

他

https://doi.org/10.5109/4566

出版情報: 九州大学大学院農学研究院紀要. 49 (1)，pp.69-75，2004-02-01. Faculty of Agriculture， Kyushu University

バージョン :

権利関係 : 


\title{
Production of Interspecific Germline Chimera between Quail and Chicken Utilizing the Cells from Central Disk of Blastoderm and Germinal Crescent Region
}

\author{
Tomoki SOH*, Yoshie INOUE ${ }^{1}$, Yong Mei XI², Yukio KATO ${ }^{3}$ \\ and Masa-Aki HATTORI
}

\author{
Laboratory of Reproductive Physiology, Division of Animal Science, Department of Animal \\ and Marine Bioresource Sciences, Faculty of Agriculture, \\ Kyushu University, Fukuoka 812-8581, Japan \\ (Received October 31, 2003 and accepted November 14, 2003)
}

\begin{abstract}
Production of interspecific germline chimera between quail and chicken was carried out using the cells from the central disk (CD) of the area pellucida in quail blastoderm (stage $\mathrm{X}$ ) and the germinal crescent region (GCR) of quail embryo (stage 7-8). The cells of CD and GCR were dispersed and injected into the subgerminal cavity of chicken blastoderm (stage $\mathrm{X}$ ). Injected eggs were incubated for 7 days or to hatching. To detect quail genomic DNA, the polymerase chain reaction was used. In day- 7 embryos, quail DNA was detected in 4 gonads and 6 brains from 55 survived embryos received quail CD cells, and 9 gonads and 8 brains from 68 survived embryos received quail GCR cells. Quail DNA was also detected from eggs or semen of adult female or male chicken hatched from eggs received quail CD or GCR cells. CD and GCR cells as the donors showed the possibility to produce the interspecific germline chimera but the necessary improvement and the immunoreactive problem were suggested.
\end{abstract}

\section{INTRODUCTION}

For the preservation of endangered species in bird like as the crested ibis, Nipponia nippon, production of interspecific germline chimeras (Naito et al., 1991; Ono et al., 1996; Ono et al., 1998a, b; Fujihara, 1999; Li et al., 2002) will be one of the useful methods. In order to facilitate the improvement of this method, gene markers, which can detect the donor cells in recipient, are very important tools. There are some gene markers for interspecific chimeras between quail and chicken (Ono, 2001; Li et al., 2001). Also, we have used another primer set for chicken ovalbumin to identify the donor chicken DNA in the recipient quail by polymerase chain reaction (PCR) in the previous study (Soh et al., 2002). In the present study, we have designed the primer set for quail ovalbumin and tried to produce interspecific germline chicken chimeras with quail cells as the donor.

1 Laboratory of Reproductive Physiology, Division of Animal Science, Department of Animal and Marine Bioresource Sciences, Graduate School of Bioresource and Bioenvironmental Sciences, Kyushu University

${ }^{2}$ Laboratory of Agricultural Ecology, Division of Agricultural Ecology, Department of Plant Resources, Graduate School of Bioresource and Bioenvironmental Sciences, Kyushu University; present address: College of Life Science, Zhenjiang University, Kai Xuan Road No. 268, Hangzhou 310029, Zhenjiang, P. R. China

${ }_{3}$ Faculty of Agriculture, Meiji University, Kawasaki 214-8571, Japan.

* Corresponding author (E-mail soht@agr.kyushu-u.ac.jp) 


\section{MATERIALS AND METHODS}

\section{Donor cells}

Fertilized quail eggs, which were freshly oviposited and incubated for $26-29 \mathrm{~h}$, were swabbed with $70 \%$ ethanol. CD of the area pellucida in blastoderm and GCR were cut off and the cells were dispersed in phosphate buffered saline (PBS) by pipetting. These cells were resuspended in Dulbecco's MEM to become 500 cells/ $\mu$ l after centrifugation ( $400 \mathrm{xg}$, $10 \mathrm{~min}$ ) and removing supernatant.

\section{Recipient eggs and injection}

Fresh and fertile chicken eggs swabbed with $70 \%$ ethanol were stored for $2-3$ days at room temperature with marked equatorial plane up. A window $5-7 \mathrm{~mm}$ in diameter was opened at the mark. Then, $1 \mu \mathrm{l}$ of donor cell suspension (500 cells) was injected into the subgerminal cavity of recipient embryo using drawn micropipette (50-70 $\mu \mathrm{m}$ outer diameter). Each window was closed with an adhesive tape. Injected eggs were incubated for 7 days or to hatching at $37.7^{\circ} \mathrm{C}$ and $70 \%$ relative humidity.

\section{Preparation of genomic DNA and progeny test}

Gonads and a part of brain were collected from the embryos at day-7. Semen was collected from an adult male chicken hatched from eggs received CD cells. The blastoderms were collected from fertilized eggs freshly oviposited by female chickens, which hatched from eggs received CD or GCR cells, artificially inseminated with chicken semen. Genomic DNA samples were extracted by the conventional method using phenol-chloroform. DNA concentration was determined by spectrophotometer at $260 \mathrm{~nm}$.

The progeny test was performed with quail hens by artificial insemination of the semen collected from chimeric male chicken.

\section{PCR}

To detect quail genomic DNA by PCR, a primer set for ovalbumin cDNA (GenBank \#X53964) was designed: primer Q1, 5'-CAGAGGCTGGAGTGGATGCTA-3' (sence) and primer Q2, 5'-TATTACTCTGTGTAAGGGAAGGGTGAAGT-3' (antisence). After an initial denaturation step $\left(95^{\circ} \mathrm{C}, 10 \mathrm{~min}\right)$, the PCR was performed in reaction mixture $(10 \mu \mathrm{l})$ containing $0.2 \mu \mathrm{M}$ each of the primers, $1 \times$ PCR buffer, $0.2 \mathrm{mM}$ dNTPs, $0.25 \mathrm{U}$ AmpliTaq Gold polymerase (Perkin Elmer Applied Biosystems, Foster, CA, USA), and 10 ng of DNA template. The amplification step consisted of 40 cycles using denaturation $\left(95^{\circ} \mathrm{C}, 30 \mathrm{sec}\right)$, annealing $\left(60^{\circ} \mathrm{C}, 30 \mathrm{sec}\right)$, and extension reaction $\left(72^{\circ} \mathrm{C}, 2 \mathrm{~min}\right)$ before a final extension step of $10 \mathrm{~min}$ at $72^{\circ} \mathrm{C}$. The PCR products, of which predicted size was $309 \mathrm{bp}$ (Fig. 1), were analyzed by electrophoresis on $1.5 \%$ agarose gels. The PCR products amplified with quail genomic DNA was checked by a restriction enzyme Bfa I (New England BioLabs, Beverly, MA, USA), and the resulting products were analyzed by electrophoresis on $1.5 \%$ agarose gels. To compare the intensities of the signals, 10,1 and $0.1 \mathrm{ng}$ of quail genomic DNA with $10 \mathrm{ng}$ of chicken DNA were used for template. Chicken genomic DNA was used as the negative control. 


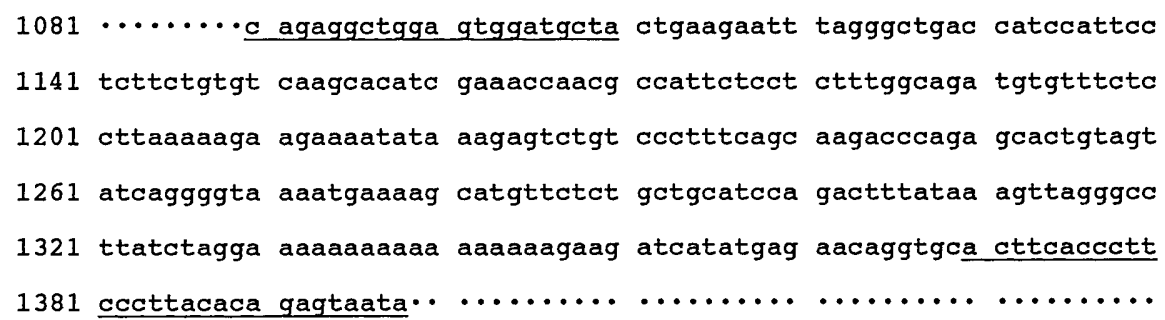

Fig. 1. Nucleotide sequence of the amplified region of quail ovalbumin cDNA (GenBank \#X53964). Underlined sequences are the primer regions.

\section{RESULTS}

\section{Verification of the PCR product}

The PCR product of the expected size ( $309 \mathrm{bp}$ ) was amplified from quail genomic DNA, and when the template decreased, the intensity of the signal weakened (Fig. 2). Chicken genomic DNA was not amplified with the primer set for quail. The $309 \mathrm{bp}$ quail PCR fragment was cleaved with Bfa I, which yielded the expected fragments of 236 and $73 \mathrm{bp}$.

\section{Detection of quail DNA in day-7 chicken embryos}

A total of 123 chicken eggs received quail CD cells. The survival rate of embryos at day-7 was $45 \%$ (Table 1). Quail DNA was detected from 4 embryos in the gonad and 6 embryos in the brain as revealed by PCR analysis. A total of 122 chicken eggs received quail GCR cells. The survival rate of embryos at day-7 was 56\% (Table 1). Quail DNA was detected from 9 embryos in the gonad and 8 embryos in the brain. The intensities of the signals of these embryos received CD or GCR cells were estimated same as or less than $1 / 100$ comparing with positive control (10 ng of quail DNA).

Table 1. Detection of quail DNA from chimeric chicken embryos at day-7 by PCR

\begin{tabular}{cccccccc}
\hline Donor & Cells & Recipient & $\begin{array}{c}\text { Injected } \\
\text { eggs }\end{array}$ & $\begin{array}{c}\text { Survived } \\
\text { embryos } \\
\text { at day-7 }\end{array}$ & $\begin{array}{c}\text { Quail DNA } \\
\text { detected } \\
\text { in gonad }\end{array}$ & $\begin{array}{c}\text { Quail DNA } \\
\text { detected } \\
\text { in brain }\end{array}$ & $\begin{array}{c}\text { Quail DNA detected } \\
\text { in both gonad } \\
\text { and brain }\end{array}$ \\
\hline Quail & $\begin{array}{c}\text { Central } \\
\text { disk of } \\
\text { blastoderm }\end{array}$ & Chicken & 123 & $\begin{array}{c}55 \\
(45 \%)\end{array}$ & $\begin{array}{c}4 \\
(7 \%)\end{array}$ & $\begin{array}{c}6 \\
(11 \%)\end{array}$ & $\begin{array}{c}0 \\
(0 \%)\end{array}$ \\
\hline Quail & $\begin{array}{c}\text { Germinal } \\
\text { crescent } \\
\text { region }\end{array}$ & Chicken & 122 & $\begin{array}{c}68 \\
(56 \%)\end{array}$ & $\begin{array}{c}9 \\
(13 \%)\end{array}$ & $\begin{array}{c}8 \\
(12 \%)\end{array}$ & \begin{tabular}{c}
$(6 \%)$ \\
\hline
\end{tabular} \\
\hline
\end{tabular}

${ }^{1}$ Fertilized eggs freshly oviposited were used.

${ }^{2}$ Fertilized eggs incubated for $26-29 \mathrm{~h}$ were used. 


\section{Detection of quail DNA in semen or eggs of adult chickens and progeny test}

Four chickens hatched from 15 eggs those were injected with quail CD cells. Three chickens grown up and they revealed two females and one male after reaching to sexual maturity. Quail DNA was detected from a part of the semen of the male (Fig. 3) or an egg of one female artificially inseminated with chicken semen (Table 2, Fig. 4). Three chickens hatched from 22 eggs those were injected with quail GCR cells. Two chickens grown up and they revealed females after reaching to sexual maturity. Quail DNA was also detected from three eggs of one female artificially inseminated with chicken semen

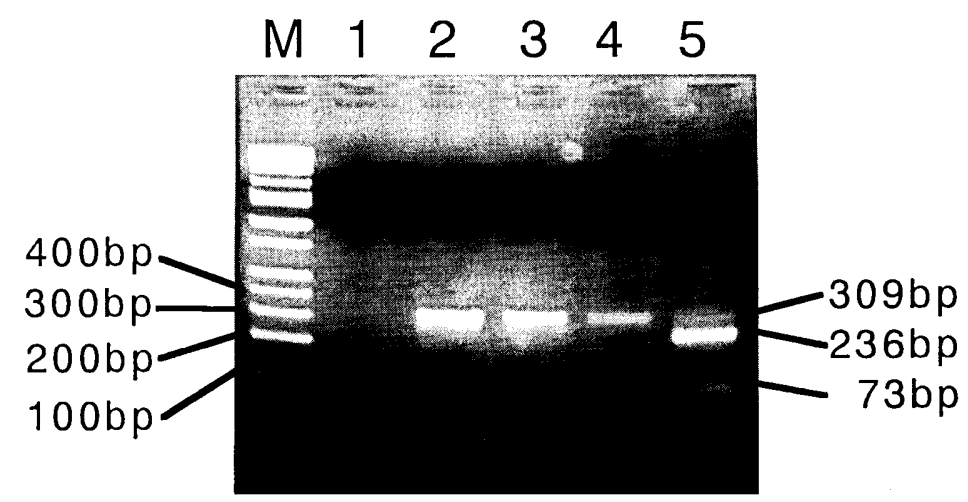

Fig. 2. Amplified PCR products from quail genomic DNA. M: Molecular size marker. 1: $10 \mathrm{ng}$ of chicken genomic DNA (negative control). 2: Quail and chicken genomic DNA (10 ng:10 ng). 3: Quail and chicken genomic DNA (1 ng:10 ng). 4: Quail and chicken genomic DNA (0.1 ng:10 ng). 4: Digestion of the amplified product with Bfa I. Digested fragments appeared $236 \mathrm{bp}$ and $73 \mathrm{bp}$.

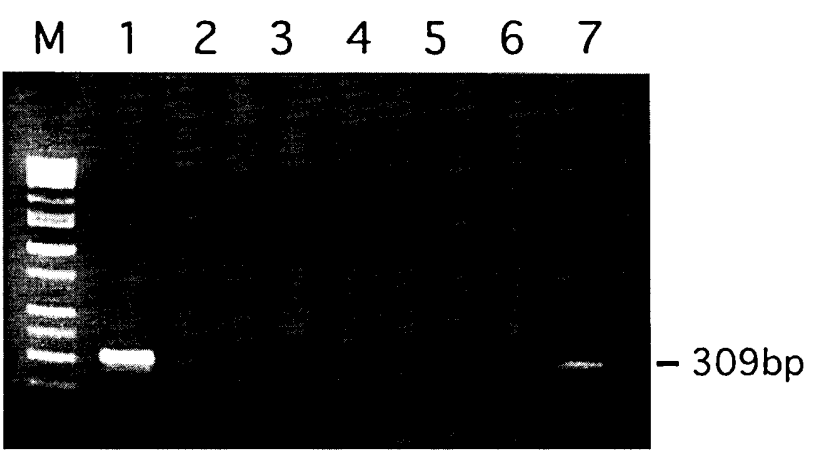

Fig. 3. Detection of quail DNA from chicken semen. M: Molecular size marker. 1: 10 ng of quail genomic DNA (positive control). 2: 10 ng of chicken genomic DNA (negative control). 3-7: Sperm samples $(10 \mu \mathrm{l})$ taken from one ejaculated semen. Quail DNA was detected from only one sample (lane 7). 


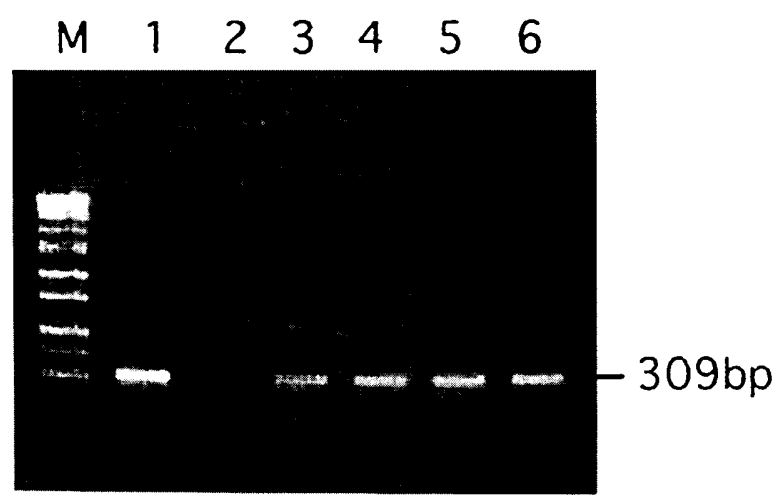

Fig. 4. Demonstration of detected quail DNA from four chicken eggs. M: Molecular size marker. 1: 10 ng of quail genomic DNA (positive control). 2: $10 \mathrm{ng}$ of chicken genomic DNA (negative control). 3-6: Blastoderms of chicken eggs from which quail DNA was detected.

Table 2. Detection of quail DNA from putative chimera chicken hens

\begin{tabular}{lccc}
\hline Donor cells & Individual No. & No. of eggs & Detected quail DNA \\
\hline Quail CD' & 62 & 44 & $1(2.3 \%)$ \\
Quail CD' & 64 & 38 & $0(0 \%)$ \\
Quail GCR & 70 & 42 & $3(7.1 \%)$ \\
Quail GCR & 73 & 33 & $0 \quad(0 \%)$ \\
\hline 'Central disk of blastoderm. & & \\
'Germinal crescent region. & &
\end{tabular}

(Table 2, Fig. 4). The semen of the chimeric male chicken was artificially inseminated to quail hens. A total of 2030 eggs were collected and incubated, but no quail and 54 hybrids hatched. In addition, the chimeric male chicken had bent left leg and the two chimeric female chickens died suddenly within two months after sexual maturity.

\section{DISCUSSION}

The Quail ovalbumin has the sequence of amino acid shorter than that of chicken as described in the previous study (Soh et al., 2002). This difference has been considering in designing the primer set. The primer set for quail ovalbumin was able to amplify PCR products with quail genomic DNA but not chicken genomic DNA in the present study. Other available primer sets to detect interspecific chimera between quail and chicken have also been reported (Ono, 2001; Li et al., 2001). As well, the peafowl-specific primers designed from cyt $\mathrm{b}$ gene sequences have been used to detect the interspecific chimera between peafowl and chicken (Xi et al., 2002). 
The chicken CD cells in blastoderm at stage X (Eyal-Giladi and Kochav, 1976) and the cells of GCR at stage 7-8 (Hamburger and Hamilton, 1951) include pre-PGCs (Ginsburg and Eyal-Giladi, 1986, 1987, 1989; Kagami et al., 1997; Tagami and Kagami, 1998; Kagami et al., 2000; Naito et al., 2001) and PGCs (Eyal-Giladi et al., 1981; Urven et al., 1988; Han et al., 1994), respectively. As the donor cells, they showed the possibility to produce the interspecific germline chimera in the previous study (Soh et al., 2002). As well, the quail CD cells and GCR cells also showed the possibility to be useful donor cells for germline chimeras since the donor quail DNA was detected in the gonad of the recipient chicken embryo and in the semen or eggs of the adult recipient chicken as revealed by PCR in this study.

The survival rate at day-7 and hatchability of manipulated chicken embryos seems to be better than those of quail embryos (Soh et al., 2002). But obtained germline chimeras were not so lot and their chimera rates were also very low as same as previous study (Soh et al., 2002). Any quail chicks have not hatched, however, the semen of the chimeric male chicken has been inseminated to quail hens. Further studies are needed to make necessary improvement as suggested in previous study (Soh et al., 2002).

There were other problems of interspecific chimeras, e.g., the sudden death and the abnormal body of chimeric chickens. All chimeric hens had been dead within two months after sexual maturity and the chimeric male chicken has bent left leg. These problems may be caused from the immunoreaction to donor cells of different species. The donor cells may have to be settled in the germline restrictedly or the somatic chimera rate has to be reduced as possible.

\section{REFERENCES}

Eyal-Giladi H. and S. Kochav. 1976 From cleavage to primitive streak formation: a complementary normal table and new look at the first stage of the development of the chicken I. Gen. Morphol. Dev. Biol., 49: 321-337

Eyal-Giladi H., M. Ginsburg and A. Farbarov 1981 Avian primordial germ cells are of epiblastic origin. J. Embryol. Exp. Morphol., 65: 139-147

Fujihara N. 1999 Poultry genetic resources and conservation biology. Jpn. Poult. Sci., 36: 127-147

Ginsburg M. and H. Eyal-Giladi 1986 Temporal and spatial aspects of the gradual migration of primordial germ cells from the epiblast into the germinal crescent in the avian embryo. J. Embryol. Exp. Morphol., 95: 53-71

Ginsburg M. and H. Eyal-Giladi 1987 Primordial germ cells of the young chick blastoderm originate from the central zone of the area pellucida irrespective of the embryo-forming process. Development, 101: 209-219

Ginsburg M. and H. Eyal-Giladi 1989 Primordial germ cell development in cultures of dispersed central disks of stage X chicken blastoderms. Gamete Res., 23: 421-428

Hamburger V. and H. L. Hamilton 1951 A series of normal stages in the development of the chick. J. Morphol., 88: 49-92

Han J. Y., D. S. Seo and R. N. Shoffner 1994 Primordial germ cells in Aves. Asian-Aust. J. Anim. Sci., 7: 459-466

Kagami H., T. Tagami, Y. Matsubara, T. Harumi, H. Hanada, K. Maruyama, M. Sakurai, T. Kuwana and M. Naito 1997 The developmental origin of primordial germ cells and the transmission of the donor-derived gamete in mixed-sex germline chimeras to the offspring in the chicken. Mol. Reprod. Dev., 48: 501-510

Kagami H., J. Iwata, A. Nakata, T. Tagami, Y. Matsubara, T. Harumi, C. Tachi, H. Okabayashi, N. Kashiwazaki, M. Shino and M. Naito 2000 Substantial evidence to localize the developmental origin of primordial germ cells in the chicken. Anim. Sci. J., 71: 38-41 
Li H. C., L. Zhao, H. Kagami, K. Matsui and T. Ono 2001 Identification of transferred chicken germ cells in quail gonad and semen by amplification of chicken-specific PCR products. J. Poult. Sci., 38: 308-316

Li Z. D., H. Deng, C. H. Liu, Y. H. Song, J. Sha, N. Wang and H. Wei 2002 Production of duck-chicken chimeras by transferring early blastdermal cells. Poultry Sci., 81: 1360-1364

Naito M., M. Watanabe, M. Kinutani, K. Nirasawa and T. Oishi 1991 Production of quail-chick chimaeras by blastoderm cell transfer. Br. Poult. Sci. 32: 79-86

Naito M., A. Sano, Y. Matsubara, T. Harumi, T. Tagami, M. Sakurai and T. Kuwana 2001 Localization of primordial germ cells or their precursors in stage $\mathrm{X}$ blastoderm of chicken and their ability to differentiate into functional gametes in opposite-sex recipient gonads. Reproduction, 121: 547-552

Ono T. 2001 Ex ovo culture of quail embryos and its application for embryo manipulation. Anim. Sci. J, 72: 361-372

Ono T., R. Yokoi and H. Aoyama 1996 Transfer of male or female primordial germ cells of quail into chick embryo gonads. Exp. Anim., 45: 347-352

Ono T., R. Yokoi, S. Maeda, T. Nishida and H. Aoyama 1998a Settlement of quail primordial germ cells in chicken gonads. Anim. Sci. Technol., 69: 546-555

Ono T., R. Yokoi, S. Maeda, T. Nishida and H. Aoyama 1998b Transfusion of chick primordial germ cells into quail embryos and their settlement in gonads. Anim. Sci. Technol., 69: 911-915

Soh T., Y. Inoue, Y. M. Xi, Y. Kato, M. A. Hattori 2002 Utilization of central disk of blastoderm and germinal crescent region for production of interspecific germline chimera between chicken and quail. Asian J. Androl., 4: 83-6

Tagami T. and H. Kagami 1998 Developmental origin of avian primordial germ cells and its unique differentiation in the gonads of mixed-sex chimeras. Mol. Reprod. Dev., 50: 370-376

Urven L. E., C. A. Erickson, U. K. Abbott and J. R. McCarry 1988 Analysis of germ line development in the chick embryo using antimouse EC cell antibody. Development, 103: 299-304

Xi Y. M., S. G. Fang, Y. Nada and N. Fujihara 2002 Indian peafowl-chicken interspecific chimera. $J$. Poult. Sci., 39: 149-158 